\title{
GADUH SAPI COOPERATION SYSTEM IN FIQH MUA'MALAH AT TANJUNG KULON KAJEN PEKALONGAN VILLAGE
}

\author{
Hendri Hermawan Adinugraha \\ State Islamic Institute of Pekalongan, hendri.bermawan@iainpekalongan.ac.id \\ Elsa Vani Mawaddah \\ State Islamic Institute of Pekalongan, elsa.vani@gmail.com \\ Ali Muhtarom \\ State Islamic Institute of Pekalongan, ali.mubtarom@iainpekalongan.ac.id
}

\begin{tabular}{|l|l|l|}
\hline Accepted: 2021-04-27 & Revised: 2021-06-28 & Published: 2021-07-31 \\
\hline
\end{tabular}

\author{
(c) (i) (2) \\ (C)2021 by the authors. Submitted for possible open access publication under the terms and conditions \\ of the Creative Commons Attribution (CC-BY-SA) license (https://creativecommons.org/licenses/by-sa/4.0/) \\ DOI : $\underline{10.30983 / \text { alhurriyah.v6i1.4211 }}$
}

\begin{abstract}
This study aims to describe the "gaduh sapi" collaboration in terms of practice and review of mu'amalah fiqh in Tanjung Kulon Village, Kajen Sub-District, Pekalongan District. This research is descriptive qualitative research. The sources used in this study are data from interviews, observations, documentation and literature data. The subjects of this study were cattle managers and owners of capital. Data collection techniques used nonparticipant observation methods, structured interviews, and documentation. The data analysis used is qualitative by using the deductive method. The study results show that the practice of "gaduh sapi" in Tanjung Kulon Village follows the habits of the village community both in terms of how to manage, provide capital, and share profits. The model of rowdy practice is carried out with two events, namely fattening and breeding. The "gaduh sapi" collaboration is carried out by the community as a means of helping. The community's practice of "gaduh sapi" cooperation is by the rules of fiqh mu'ämalah, namely using a mudärabah contract. Because the financier gives the business manager the freedom to manage his business, develop it without limiting the type, time and place. The capital used in this rowdy cooperation practice is goods, namely cows. It is in line with one of the conditions for mudarabah capital: money or goods valued (cows are included). So that at the end of time can distinguish the distribution of results. Where cattle capital remains the right of the owner of the capital, then the fattening and breeding results are shared. The provisions of the benefits carried out by the people of Tanjung Kulon Village are hand in hand with the rules of al-ghunmu bi al-ghurmi (risks are balanced with benefits). This study also confirms that there are no contracts containing gharar in the "gaduh sapi" practice.
\end{abstract}

Keywords: Cooperation, Gaduh Sapi, Fiqh Mu'āmalah

\begin{abstract}
Abstrak
Penelitian ini bertujuan untuk mendeskripsikan "gaduh sapi" dari segi praktik dan tinjauan fiqh mu'ämalah di Desa Tanjung Kulon, Kecamatan Kajen, Kabupaten Pekalongan. Penelitian ini termasuk penelitian kualitatifyang bersifat deskriptif. Sumber yang digunakan dalam penelitian ini yaitu data hasil wawancara, observasi, dokumentasi, dan data literatur. Subjek penelitian ini adalah pengelola sapi dan pemilik modal. Teknik pengumpulan data menggunakan metode observasi non-partisipan, wawancara terstruktur, dan dokumentasi. Analisis data yang digunakan adalah kualitatif dengan menggunakan metode deduktif. Hasil penelitian menunjukan bahwa praktik "gaduh sapi" di Desa Tanjung Kulon mengikuti kebiasaan masyarakat desa baik dari segi cara pengelolaan, penyediaan modal, dan pembagian keuntungan. Model praktik gaduh yang dilakukan dengan dua acara yaitu penggemukan dan pengembangbiakan. Kerjasama "gaduh sapi" yang dilakukan oleh masyarakat sebagai sarana tolong menolong. Praktik kerjasama "gaduh
\end{abstract}


sapi” yang dilakukan masyarakat sudah sesuai dengan aturan fiqh mu'amalah, yaitu menggunakan akad mudàrabah. Pengelola usaba diberi kebebasan oleh pemilik modal untuk mengelola usahanya, mengembangkan tanpa memberibatasan jenis, waktu serta tempat. Modalyang digunakan dalam praktik kerjasama gaduh ini adalah barang yaitu sapi. Hal ini sudah sesuai dengan salah satu syarat modal mudärabah yaitu dapat berbentuk uang atau barang yang dinilai (sapi termasuk di dalamnya). Pada waktu akbir pembagian hasil dapat dibedakan dari keuntungan. Dimana modal sapi tetap menjadi bak pemilik. modal, selanjutnya hasil penggemukan dan pengembangbiakan yang dibagihasilkan. Ketentuan keuntungan yang dilakukan masyarakat Desa Tanjung Kulon telah sesuai dengan kaidah al-ghunmu bi al-ghurmi. Hasil penelitian ini juga menegaskan bahwa tidak ditemukan akadyang mengandung gharär dalam praktik. "gaduh sapi" disana.

Kata Kunci: Kerjasama, Gaduh Sapi, Fiqh Mu’āmalah.

\section{INTRODUCTION}

Islam is a rabmatan lil a'lamin religion. It manages worship and mu'amalab aspects in detail and clearly. ${ }^{1}$ The human being as a social being needs other people to fulfil their needs, corporation, and mutual assistance.

In Islam, it is called mu'amalah. One of the characteristics of mu'amalah is profit-sharing practice with mutual assistance principle (ta'äwun). ${ }^{2}$

Based on society's reality, some businessmen have capital but do not have skill and time. Conversely, people have capital and skill but do not have much time because of their busyness. However, some people have time and skill but do not have capital. Therefore, humans do corporation to fulfil their needs. ${ }^{3}$ It is also conducted by the people of Tanjung Kulon village who have livelihoods as traders, farmers, and cattlemen.

Most of the people in this district go to Jakarta as a trader. They have the capital to make a new business in their hometown.

${ }^{1}$ Muhammad Makmun Rasyid, 'Islam Rahmatan Lil Alamin Perspektif KH. Hasyim Muzadi', Epistemé: Jurnal Pengembangan Ilmu Keislaman, 11.1 (2016): 93, <https://doi.org/10.21274/epis.2016.11.1.93-116>.

2 Nurhadi, 'Konsep Pelayanan Perspektif Ekonomi Syariah', EkBis: Jurnal Ekonomi Dan Bisnis, 2.2 (2020): <https://doi.org/10.14421/ekbis.2018.2.2.1100>.

${ }^{3}$ Govi Tri Saputra, 'Formulasi Klausula Force Majeure Dalam Kontrak Dagang Internasional', JuristDiction, $3.3 \quad$ (2020): 991, <https://doi.org/10.20473/jd.v3i3.18634>.
They also buy cows for breeding. Yet, most of them do not have time to take care of those cows because they have to go to Jakarta to trade again.

Therefore, they trust their neighbours, who have much time and skill to protect and develop their cows. Cooperation in this cattle field is called gaduh (sharing profit system in animal husbandry business) by people in Tanjung Kulon Village, Kajen Sub-District).

Gaduh is a profit-sharing system in the agriculture and animal husbandry business. Normally, a half or one-third of business results is used for gaduh. ${ }^{4}$ This gadub cooperation is often used by Tanjung Kulon Village society with sharing profit system mechanism between cattleman and the owner of cows. This sharing profit system can help poor cattlemen to fulfil their economic needs. ${ }^{5}$

Moreover, grass as cow feed is not difficult to gain because there are so many fertile acreages containing grass in Tanjung Kulon Village, Kajen Sub-District.

4 Berkah Subaiti, Istianah Istianah, and Wage Wage, 'Pandangan Hukum Islam Terhadap Kerja Sama Gaduh Sapi Di Desa Lembupurwo Kecamatan Mirit Kabupaten Kebumen', Jurnal Hukum Ekonomi Syariah, 2.1 (2019): <https://doi.org/10.30595/jhes.v2i1.4474>.

${ }^{5}$ Susi Tri Wahyuni and Kusni Hidayati, 'Program Pengembangan Kandang Intensif Ternak Sapi Gaduh Di Trenggalek', Ekobis Abdimas: Jurnal Pengabdian Masyarakat, $\quad 1.2 \quad$ (2020): 144 , <https://doi.org/10.36456/ekobisabdimas.1.2.3035>. 
For the owner of the cows, this gaduh cooperation is used for investment and business. Meanwhile, it is used for getting income for cattlemen based on that sharing profit. Thus, this gaduh corporation system gives benefit to the cattleman and the owner of the cows.

In Islam, gaduh cooperation is part of mu'amalah activity. Based on mu'amalah regulation, it has to be harmonic with fiqh mu'āmalah.

fiqh mu'amalab is a law following human behave in world affairs, such as buy and sell matter, ${ }^{6}$ Debt, trade cooperation, organization, cultivate cooperation, and tenancy. ${ }^{7}$

Gadub sapi cooperation conducted by people in Tanjung Kulon Village has become a tradition. It occurs because there is a willingness ('an taräạin) between cattlemen and financier. The cattleman maintains cows for getting income throughout gadub sapi cooperation. Meanwhile, financiers try to do investments because they do not have enough time to maintain the cows. In Tanjung Kulon Village, gadub sapi cooperation is usually conducted based on a verbal agreement. There is no written agreement. The reason is they are in the same area and have known each other. Therefore, the researcher is interested in discussing this gaduh practice. It is conducted to respond to the people who consider this practice is not under shari'ah and fiqh mu'āmalah.

Gadub sapi coorporation in Tanjung Kulon Village is allowed in Islam. It is classified into a business that obtains a blessing. The Prophet of Muhammad saw said:

6 M. Yusuf Azwar Anas, 'Perspektif Ulama Terhadap Akad Murabahah Untuk Modal Usaha Mikro', DIALEKTIKA: Jurnal Ekonomi Dan Ilmu Sosial, 1.1 (2017): <https://doi.org/10.36636/dialektika.v1i1.22>.

${ }^{7}$ Sulaiman Rasjid, Figh Islam, (Bandung: Sinar Baru Algensido, 2017), 51.
"There are three things contain blessing: buy and sell by credit,

muqāradah (mudārabah), and combining wheat with jawawnut for bousehold matters, not to be sold" (Hadith narrated by Ibn Majah from Shuhaib).

Based on the type, this research is field research. ${ }^{8}$ The research aims to gather data from a location, namely Tanjung Kulon Village, Kajen Sub-District, Pekalongan District. It is also descriptive analysis because this research describes the situation and event of gaduh sapi cooperation practice in Tanjung Kulon Village, Kajen Sub-District, Pekalongan District.

This descriptive research specialized in observation and natural settings. ${ }^{9}$ This research used several sources: a). Primary data such as interview results, observation, and documentation in Tanjung Kulon Village, Kajen Sub-District, Pekalongan District, and b) Secondary data is obtained from the library by reading, reviewing, and taking some note from several kinds of literature related to the fiqh mu'amalah of gaduh sapi cooperation practice in Tanjung Kulon Village, Kajen SubDistrict, Pekalongan District. This research is a cattleman who protects the cows and financiers as the cows' owner.

The data is collected using the un participant observation method. The researcher does not participate in conducting the activity that is analyzed directly, systematic interview where the questions are asked through an interview guide. Those questions are prepared before conducting the research. The last is documentation such as a private

8 Mildred L. Patten and Mildred L. Patten, 'Qualitative Research Design', in Understanding Research Methods, 2018: 29, <https://doi.org/10.4324/9781315213033-51>.

9 Jeremy Jolley and Jeremy Jolley, 'Qualitative Research in Practice', in Introducing Research and EvidenceBased Practice for Nursing and Healthcare Professionals, 2020: 21, <https://doi.org/10.4324/9780429329456-10>. 
note, private latter, diary, work report, meeting note, case note, cassette recording, video recording, photo, and other matters in gaduh sapi cooperation practice Tanjung Kulon Village, Kajen Sub-District, Pekalongan District. To the data analysis this research used qualitative research by applying the deductive method. This method is used to implement the agreement of gadub sapi in Tanjung Kulon Village, Kajen Sub-District, Pekalongan District. Field data is combined with the data from some kinds of literature, from a general view it takes a specific conclusion.

Based on the background above, the purpose of this research is not only to describe gaduh sapi cooperation practice in Tanjung Kulon Village, Kajen Sub-District, Pekalongan District, but also to describe figh mu'amalah perspective towards it. This research aimed to respond to an issue in some communities in Tanjung Kulon Village, Kajen Sub-District, Pekalongan District. The issue is that gaduh sapi contains gharair agreement, trickery, and exploitation. Therefore, the researcher needs to discuss it directly.

\section{COOPERATION IN MU'ĀMALAH PERSPECTIVE}

FIQH

In Islam, there are so many types of mu'amalah. One of them is a profit-sharing practice considered by the mutual assistance aspect. $^{10}$ Islam views business activity

10 Zarul Arifin, 'Praktik Bagi Hasil Pengelolaan Lahan Perkebunan Kelapa Sawit Pada Koperasi Cempaka Biru Kecamatan Sejangkung Kabupaten Sambas Perspektif Hukum Islam', Al-Istinbath: Jurnal Hukum Islam, 5.1 (2020): 141 , <https://doi.org/10.29240/jhi.v5i1.1332>.

11 Shobirin, 'Jual Beli Dalam Pandangan Islam', BISNIS: Jurnal Bisnis Dan Manajemen Islam, 3.2 (2016): 239, < https://doi.org/10.21043/bisnis.v3i2.1494>.

12 Maryani, 'Kerjasama/Syirkah Dalam Bisnis Islam', Iqtishodiyah: Jurnal Ekonomi Dan Bisnis Islam, 4.1 (2018):

<https://doi.org/10.36835/iqtishodiyah.v4i1.78>. (economic) as one of the glorious purposes. Thus, people who practice this religion are given ease in conducting business activity as long as it is in line with Islamic law. ${ }^{11}$

Moreover, cooperation is a relationship between two people or more in distributing benefit or loss in a business where both people or one of them will endure the loss. ${ }^{12}$ Two people work together because they cannot conduct the business alone. It occurs because of minimum capital, minimum knowledge, etc.

In mu'amalah, profit sharing practice is called as mudarabab. ${ }^{13}$ The term of Mudārabah arises from the word $a l-D a r b$. It means to hit or walk. The meaning of the words hit and walk is one's process to use his foot to conduct a business. ${ }^{14}$ Mudārabah also has equal meaning with qiräd. Qiräd comes from the word al-qard. It means cutting. It is because financiers cut some of their wealth to be traded for gaining benefit. $^{15}$

In fiqh mu'amalah, the definition of mudarabah agreement is a cooperation agreement that contains capital or equal matter in the specific quantity, type, and character of capital from financier to manager can be used as a valuable business. ${ }^{16}$ In other words, mudarabab is giving a certain wealth from one to the other people to be a venture capital by those people. Then, the profit is divided based on the regulations that have been agreed upon

13 Jalaluddin and Ambok Pangiuk, 'Bagi Hasil (Studi Tentang Implikasi Konsep Maqasid Al-Syariah AlSyatiby)', Indonesian Journal of Islamic Economics and Business, 1.1 (2016): 133.

14 Firdaweri, 'Perikatan Syari'ah Berbasis Mudharabah (Teori Dan Praktik)', Asas, 6.2 (2014): 54.

15 Nining Sri Wahyuni, 'Analisis Fikih Sistem Pembiayaan Mudharabah Dalam Praktik Dan Peraturan Perundang-Undangan Perbankan Syari'ah', Fitrab:Jurnal Kajian Ilmu-Ilmu Keislaman, 2.1 (2016): 105 , <https://doi.org/10.24952/fitrah.v2i1.458>.

16 Amir Syarifuddin, 'Garis-Garis Besar Fiqh', Katalog Perpustakaan Badan PPSDMK Kemenkes RI, 2010, 33. 
by financiers and people who utilize the capital.

\section{GADUH SAPI COOPERATION PRACTICE IN TANJUNG KULON VILLAGE KAJEN SUB-DISTRICT PEKALONGAN DISTRICT}

Gadub sapi cooperation occurs in Tanjung Kulon Village because of the willingness of cattlemen and the owner of cows. Cattleman want to gain additional income by cooperating with the owner of cows. Meanwhile, the cows' owner wants to make an investment but does not have time to protect his cows.

Gaduh sapi cooperation is often used based on a verbal agreement. There is no written agreement. The cattleman and the owner of the cows know each other, and they also live in the same village.

There are three parts in gaduh sapi cooperation practice conducted by people in Tanjung Kulon. They are as follows:

\section{1) Provision of Capital and Instrument}

The owner of the cows provides the provision of capital and instrument. The first capital is a cow breeder bought by financier cash.

Cattleman give some price ranges of the cows or just request good cows without mentioning the price of the cows to the owner of the cows.

The cows' owner also helps to provide a cowshed if the cattleman does not have it yet. In Tanjung Kulon Village, cattleman usually have cowshed.

Table 1. Gaduh sapi business estimated cost (The owner of the cows)

\begin{tabular}{lcc}
\hline \multicolumn{1}{c}{ Cost } & Total & $\begin{array}{c}\text { Amount of } \\
\text { Cost (Rp) }\end{array}$ \\
\hline Fixed Cost & & \\
\hline Cow breeder & 1 & $\mathrm{Rp} 15.000 .000$ \\
\hline Unfixed Cost & & \\
\hline Cowshed & & $\mathrm{Rp} 1.000 .000$ \\
\hline Total cost & $\mathrm{Rp} 16.000 .000$ \\
\hline
\end{tabular}

Source: Observation result, 2021.

Meanwhile, cattleman spend money to buy an instrument, feed, and cowshed. The instrument used was scythe for cutting, a sack for grass, and a pail for cow drink.

\begin{tabular}{lcc}
\multicolumn{3}{l}{ Table 2. Gaduh sapi Business Cost (cattleman) } \\
\hline Cost & Total & $\begin{array}{c}\text { Amount of Cost } \\
\text { (Rp) }\end{array}$ \\
\hline Scythe & 1 & Rp 150.000 \\
\hline Sack & 1 & Rp 10.000 \\
\hline Pail & 1 & Rp 30.000 \\
\hline Total Cost & Rp 190.000 \\
\hline Source: Observation result, 2021.
\end{tabular}

\section{2) Breeding and Fattening}

Gadub sapi cooperation practice is usually conducted in two ways, such as breeding and fattening. Thus, the cattleman and the cows' owner agree on whether the cows will get breeding or get fattening. This agreement is conducted in the first cooperation agreement.

The owner of the cow conducts the process of cow breeding and gives a female calf of a cow. It is also known as pedet. The age of pedet is three months. It needs 14 months for breeding until the cow getting birth. If cow calves have two calves, it is divided into 2 (each cattleman and the cows' owner get one calf without selling the cow breeder). If a cow breeder calves one calf, then each cattleman and the cows' owner get half of the calf. It is called parohan sapi.

The process of cow fattening is usually used to bullock. It needs six months to obtain the fat bullock. After the fattening process gets successful, the cattleman will sell the bullock. The selling result will be divided into 2. Each cattleman and owner of the cows know the price of cows before conducting gaduh practice. For example, in the previous purchase, the price of the bullock was $\mathrm{Rp}$ 7.000.000. Then, after the fattening process, it is sold for Rp 15.000.000. Thus, there is a 
benefit as much as $\mathrm{Rp} 8.000 .000$. Therefore each cattleman and the owner of the cows get a profit of $\mathrm{Rp} 4.000 .000$.

\section{3) The portion of Profit Sharing}

In gaduh cooperation practice, people of Tanjung Kulon Village use 50:50 profitsharing type.

Where the cattleman gets $50 \%$, and the owner of the cows gets $50 \%$ as well. The result of profit-sharing from that gaduh sapi cooperation practice is divided into equal distribution based on the agreement that has been agreed. Thus, the concept of profitsharing of breeding and fattening can be described as bellow:

Table 3. Profit-Sharing Distribution in Breeding and Fattening

\begin{tabular}{|c|c|c|}
\hline Gaduh Type & Calculation & $\begin{array}{l}\text { Percentage of } \\
\text { sharing profit }\end{array}$ \\
\hline \multicolumn{3}{|l|}{ Breeding } \\
\hline $\begin{array}{l}\text { e.g., Cow calves, } \\
\text { one calf }\end{array}$ & $\begin{array}{c}\text { The selling } \\
\text { price of } 1 \\
\text { calf } / 2\end{array}$ & $\begin{array}{l}7.000 .000 / 2= \\
3.500 .000 \\
\text { Des: cattleman and } \\
\text { owner get profit- } \\
\text { sharing Rp } 3.500 .000 \\
\text { without selling cow } \\
\text { breeders. }\end{array}$ \\
\hline $\begin{array}{l}\text { e.g., Cow calves, } \\
\text { two calfs }\end{array}$ & $\begin{array}{c}\text { Two calfs } \mathrm{x} \\
\text { selling price } / 2\end{array}$ & $\begin{array}{l}\frac{2 \times 7.000 .000}{214.000 .000} \\
14.000 .000 / 2=7.000 .0 \\
00 \\
\text { Des: cattleman and } \\
\text { owner get profit- } \\
\text { sharing Rp. } 7.000 .000 \\
\text { without selling cow } \\
\text { breeders. }\end{array}$ \\
\hline Fattening & & \\
\hline
\end{tabular}

${ }^{17}$ Zainil Ghulam, 'Relasi Fiqh Muamalat Dengan Ekonomi Islam', Iqtishoduna, 8.2 (2016): 128.

\begin{tabular}{cl}
\hline The prize of & $15.000 .000-$ \\
cow- & $7.000 .000 / 2=$ \\
capital/2 & 4.000 .000 \\
& Description: cattleman \\
& and the owner get \\
& profit-sharing Rp \\
& 4.000 .000$. Meanwhile, \\
& the first capital used to \\
& buy a calf (pedet) \\
& becomes the owner's \\
& right.
\end{tabular}

Source: Observation result, 2021.

\begin{tabular}{lcr} 
FIQH MU'ĀMALAH & \multicolumn{2}{c}{ PERSPECTIVE } \\
TOWARDS & GADUH & SAPI \\
CORPORATION & SYSTEM & IN \\
TANJUNG KULON VILLAGE &
\end{tabular}

Gadub cooperation practice in Tanjung Kulon Village uses a profit-sharing system by mutual assistance. In Islam, cooperation agreement of profit-sharing is mostly called as mudärabah agreement. The term of mudarabah or qiräd is one of the syirkah agreements or partnership. ${ }^{17}$

The term of mudarabab or qirä is giving a certain wealth from one to the other people to be a venture capital by those people. Then, the profit is divided based on the regulations that have been agreed upon by financiers and people who utilize the capital. ${ }^{18}$

In this context, one who has a skill called as mudarib, while one who has a capital called as săbib al-māl. In Islam, it is allowed if one wants to use his money for a cooperation business, such as qirād or mudàrabah. Sometimes, some people have wealth but are not able to manage and produce that wealth. Some people do not have wealth but have the skill to productize it. Therefore, syari'at allows
${ }^{18}$ Desi Asmaret, 'Ontologi Hukum Islam', Jurnal Al-Himayah, 2.1 (2018): 59. 
this mu'amalab so that cattlemen and financiers can get a benefit. ${ }^{19}$

\section{1) Position of Mudarabah Agreement in Fiqh Mu'āmalah}

Mudarabab law is diverse. It depends on the situation and condition of the mu'amalah. Likewise, the position of wealth used for capital in mudarabah/ qiräd also depends on the condition. ${ }^{20}$ In this case, the capital manager (cattleman) has to get permission from the cows' owner to manage his cows. Thus, the cattleman represents the owner of the cow in the management. The position of capital (cow) is as wikälah a'laib (wakälah object). ${ }^{21}$ When a cow gives to the cattleman, the cow is under cattleman authority. Yet, it has to be remembered that the cow is not his. Thus, the position of the cow is only a trusteeship.

In mudārabab agreement, when a business gets a loss, then that loss is endured by financier / șähib al-mäl as long as that loss does not happen because of cattleman's neglect/mudärib.

Meanwhile, cattlemen/mudärib has spent his effort and time. If the capital manager neglect/mudarib causes that loss, he is responsible for the loss. ${ }^{22}$ If the cow is dead or lost is not because of

19 Ai Siti, Ifa Hanifia Senjiat, and Amrullah Hayatudin, 'Tinjauan Fiqh Muamalah Tentang Upah Pemeliharaan Hewan Ternak Pada Akad Ijarah (Praktik Gaduh Sapi)', Prosiding Hukum Ekonomi Syariah, 2020: 31. $<$ https://doi.org/10.29313/syariah.v0i0.19340>.

${ }^{20}$ Muhammad Syarif Hidayatullah, 'Implementasi Akad Berpola Kerja Sama Dalam Produk Keuangan Di Bank Syariah (Kajian Mudharabah Dan Musyarakah Dalam Hukum Ekonomi Syariah)', Jurnal Hadratul Madaniyah, $\quad 7.1 \quad$ (2020): 34, <https://doi.org/10.33084/jhm.v7i1.1613>.

${ }^{21}$ Siti Hasnaa Madinah, Putri Karunia Sari, and Isnaini Rofiqoh, 'Analisis Akad Wakalah Bil Ujrah Pada Jasa Titip Beli Online Dalam Prespektif Kaidah Fikih Ekonomi (Studi Kasus Pada Akun Instagram (ajastiperopa777)', El-Qist: Journal of Islamic Economics and Business $\quad$ (JIEB), $9.2 \quad$ (2019): 196 , <https://doi.org/10.15642/elqist.2019.9.2.196-214>. manager neglect, there is no obligation to replace it. It is also vice versa. The manager has to replace it if he is careless in his responsibility.

There is a case where a cow gets lost because someone steals it in Tanjung Kulon Village. Meanwhile, the cattleman has kept the cowshed. Usually, the cowshed is around a cattleman house. As a result, because it is a calamity, not the carelessness of cattlemen, the loss is only endured by the cows' owner. The owner of the cows endures the stolen cow. Yet, this phenomenon is very rare because Tanjung Kulon Village is a safe area. There are still people who maintain cows and goats in this area, whether for increasing income or gadub business.

Mudarabah consists of two parts based on its agreement. They are capital managers and financiers. If there is a profit in business management, then the profit is divided into two, regarding the accumulation that has been agreed. ${ }^{23}$ Mudiarabah is treated as syirkah because it looks for profit, whether for a financier or capital manager. ${ }^{24}$ Regarding the profit, the business manager gets a commission as a payment for his effort. Meanwhile, the financier obtains benefits from the capital that has been given to a business manager. ${ }^{25}$ In this

22 Syamsul Sanjaya, 'Modal Sosial Sistem Bagi Hasil Dalam Beternak Sapi Pada Masyarakat Desa Purwosari Atas, Kecamatan Dolok Batu Nanggar Kabupaten Simalungun', Perspektif Sosiologi, 3.1 (2015): 18.

${ }^{23}$ Vendra Irawan, 'Kajian Tentang Kedudukan Agunan Dalam Akad Pembiayaan Mudharabah Pada Bank Syariah', Al Hurriyah: Jurnal Hukum Islam, 4.2 (2019): 129 <https://doi.org/10.30983/alhurriyah.v4i2.965>.

24 Hendri Hermawan Adinugraha, 'Penerapan Kaidah Al-Ghunm Bi Al-Ghurm Dalam Pembiayaan Mushārakah Pada Perbankan Syariah', Economica, 8 (2017): 81.

25 Khairan, 'Strategi Membangun Jaringan Kerjasama Bisnis Berbasis Syariah', Jurnal Pemikiran Keislaman, $29.2 \quad$ (2018): <https://doi.org/10.33367/tribakti.v29i2.597>. 
case, the financier gets calves from the breeding or fattening process of cows.

\section{2) Mudārabah Pillar and Requirement}

In gaduh sapi cooperation practice, Tanjung Kulon Village has fulfilled the pillar and requirement of sharing profit cooperation of Mudiarabah.

Based on Syafi'iyah scholars, there are six pillars of mudarabah agreement such as: ${ }^{26}$ The owner who gives the product: in gaduh sapi practice, the owner is the owner of cows/financier; worker; it is called cattleman/business manager in gaduh sapi practice; mudärabah agreement. An ijab said by the cows' owner and qobul answered by the cattleman; $M \bar{a} l$ is commonly called capital. The cow is the capital of gaduh practice; 'Amal, 'amal is a gaduh process that produces a profit; and profit ratio in profit sharing.

Requirement of mudarabah agreement in gaduh sapi cooperation practice in Tanjung Kulon Village can be classified into four parts:

a. Agreement

Gaduh sapi cooperation practice in Tanjung Kulon Village is already in line with Islam law because whether cattlemen or cows' owners say ijab and qobul verbally without being forced by other people. Thus, the cooperation agreement of both people becomes a willing and sincere agreement.

Financier agrees to contribute his capital to the business manager of cows. In this case, the capital is cows. Cattleman also agrees to give a contribution to this business.

b. People who do agreement

At least two people do the agreement. They are financiers (owners of the cows) and workers. The financier has the responsibility to give his cows to the worker. Meanwhile, the worker has to keep the animal of the owner. The financier does not have an obligation to keep the animal. Yet, he is allowed to do a controlling process. People who do an agreement have to be able to conduct tasarruf. It is one's ability to do transactions, and mu'amalab to the other people considered proper people based on the requirement. Thus, this agreement is cancelled if it is conducted with children. It means people who do the agreement are adults.

c. Capital

The requirement of gaduh sapi conducted by Tanjung Kulon village society has been fulfilled. Where the prize of cows is known by financiers and business managers clearly and transparently, in this case, capital (cows) is given through tawajjuh to the business manager. Thus, in this gaduh practice, capital ( $m a \bar{a})$ is cows. It is not always about money. It is because cows are considered as an asset that given by saabib al-māl to the manager (mudàrib) for business purposes with requirements: 1). Total and type of capital have to be known, 2). Capital can be money or animal (cows) that have value, 3). Modal cannot be a credit modal and must be paid to mudarib, whether in instalment or not, based on the agreement. This matter is already in line with muḍārabah requirement because financiers and cattlemen can know the product's type and value from the beginning. Therefore, they also can distinguish profit-sharing at the end of time. The capital of cows is still right of financier, and only breeding and fattening become profit sharing.

d. Profit-sharing

Profit-sharing is determined from the beginning of the agreement. It also has to be
26 M. Yusuf Azwar Anas, 'Perspektif Ulama Terhadap Akad Murabahah Untuk Modal Usaha Mikro',
Dialektika: Jurnal Ekonomi Dan Ilmu Sosial, 1.1 (2017): 22, <https://doi.org/10.36636/dialektika.v1i1.22>. 
agreed upon by the financier and capital manager.

Profit-sharing of gaduh sapi is conducted by the Tanjung Kulon Village community proportionally. The mechanism is a 50:50 profit-sharing mechanism. On the other hand, if this business gets the loss, then the financier is the one who endures the loss, as long as the business manager does not cause that loss. The form of loss is like the death of a cow. A profit-sharing of breeding and fattening can be seen in table 3 above.

The regulation of profit-sharing conducted by Tanjung Kulon Village is hand in hand with the al-ghunmu bi al-ghurmi aspect (risk is equal with benefit). It is also in line with the hadith of the Prophet that: "benefit (is gained by one) caused he endures the risk" ((Hadith narrated by Tirmidhi).

\section{CONCLUSION}

In Tanjung Kulon Village, gaduh sapi practice follows the tradition of its society whether in managing aspects, capital provision, and profit-sharing. Gadub practice is conducted in two ways: breeding and fattening. Gaduh sapi cooperation is conducted not only for a business but also as a mutual assistance matter by giving capital to people who do not fulfil their needs.

Gadub sapi cooperation practice conducted by Tanjung Kulon Village society is already in line with fiqh mu'amalah, using mu'amalah agreement, which is mudarabah. The financier gives a business manager the freedom to manage and develop his business without limiting type, time, and condition. The requirement of sharing profit conducted by Tanjung Kulon Village is hand in hand with fiqh law using 50:50 profit-sharing mechanism from the gaduh process where financiers and business managers have equality of willing and sincere condition. 


\section{BIBLIOGRAPHY}

Adinugraha, Hendri Hermawan, 'Penerapan Kaidah Al-Ghunm Bi Al-Ghurm Dalam Pembiayaan Mushārakah Pada Perbankan Syariah Pendahuluan Konsep Dasar Dalam Perbankan Syariah Ialah Konsep Pembagian', Economica, 8 (2017), 81-102

Anas, M. Yusuf Azwar, 'Perspektif Ulama Terhadap Akad Murabahah Untuk Modal Usaha Mikro', Dialektika:Jurnal Ekonomi Dan Ilmu Sosial, $1.1 \quad$ (2017) <https://doi.org/10.36636/dialektika.v1i1.22>

Arifin, Zarul, 'Praktik Bagi Hasil Pengelolaan Lahan Perkebunan Kelapa Sawit Pada Koperasi Cempaka Biru Kecamatan Sejangkung Kabupaten Sambas Perspektif Hukum Islam', AlIstinbath : Jurnal Hukum Islam, 5.1 (2020) <https://doi.org/10.29240/jhi.v5i1.1332>

Asmaret, Desi, ‘Ontologi Hukum Islam’, Jurnal Al-Himayah, 2.1 (2018)

Firdaweri, 'Perikatan Syari'ah Berbasis Muḍārabah (Teori Dan Praktik)', Asas, 6.2 (2014)

Ghulam, Zainil, 'Relasi Fiqh Muamalat Dengan Ekonomi Islam', Iqtishoduna, 8.2 (2016)

Hidayatullah, Muhammad Syarif, 'Implementasi Akad Berpola Kerja Sama Dalam Produk Keuangan Di Bank Syariah (Kajian Muḍāabah Dan Musyarakah Dalam Hukum Ekonomi Syariah)', Jurnal Hadratul Madaniyah, 7.1 (2020) < https://doi.org/10.33084/jhm.v7i1.1613>

Irawan, Vendra, 'Kajian Tentang Kedudukan Agunan Dalam Akad Pembiayaan Muḍārabah Pada Bank Syariah', Al Hurriyah: Jurnal Hukum Islam, 4.2 (2019) <https://doi.org/10.30983/alhurriyah.v4i2.965>

Jalaluddin, Jalalludin, and Ambok Pangiuk, 'Bagi Hasil (Studi Tentang Implikasi Konsep Maqasid Al-Syariah Al-Syatiby)', Indonesian Journal of Islamic Economics and Business, 1.1 (2016)

Jolley, Jeremy, and Jeremy Jolley, 'Qualitative Research in Practice', in Introducing Research and Evidence-Based Practice for Nursing and Healthcare Professionals, 2020 $<$ https://doi.org/10.4324/9780429329456-10>

Khairan, Khairan, 'Strategi Membangun Jaringan Kerjasama Bisnis Berbasis Syariah', Jurnal Pemikiran Keislaman, 29.2 (2018) < https://doi.org/10.33367/tribakti.v29i2.597>

Madinah, Siti Hasnaa, Putri Karunia Sari, and Isnaini Rofiqoh, 'Analisis Akad Wakalah Bil Ujrah Pada Jasa Titip Beli Online Dalam Prespektif Kaidah Fikih Ekonomi (Studi Kasus Pada Akun Instagram @jastiperopa777)', El-Qist: Journal of Islamic Economics and Business (IIEB), 9.2 (2019) $<$ https://doi.org/10.15642/elqist.2019.9.2.196-214>

Maryani, 'Kerjasama/Syirkah Dalam Bisnis Islam', Iqtishodiyab: Jurnal Ekonomi Dan Bisnis Islam, 4.1 (2018) <https://doi.org/10.36835/iqtishodiyah.v4i1.78>

'Modal Sosial Sistem Bagi Hasil Dalam Beternak Sapi Pada Masyarakat Desa Purwosari Atas, Kecamatan Dolok Batu Nanggar Kabupaten Simalungun', Perspektif Sosiologi, 3.1 (2015)

Nurhadi, Nurhadi, 'Konsep Pelayanan Perspektif Ekonomi Syariah', EkBis: Jurnal Ekonomi Dan Bisnis, 2.2 (2020) <https://doi.org/10.14421/ekbis.2018.2.2.1100>

Patten, Mildred L., and Mildred L. Patten, 'Qualitative Research Design', in Understanding Research 
Methods, 2018 <https://doi.org/10.4324/9781315213033-51>

Rasyid, Muhammad Makmun, 'Islam Rahmatan Lil Alamin Perspektif KH. Hasyim Muzadi', Epistemé: Jurnal Pengembangan Ilmu Keislaman, $11.1 \quad$ (2016) $<$ https://doi.org/10.21274/epis.2016.11.1.93-116>

Saputra, Govi Tri, 'Formulasi Klausula Force Majeure Dalam Kontrak Dagang Internasional', Jurist-Diction, 3.3 (2020) <https://doi.org/10.20473/jd.v3i3.18634>

Shobirin, Shobirin, 'Jual Beli Dalam Pandangan Islam', BISNIS: Jurnal Bisnis Dan Manajemen Islam, 3.2 (2016) < https://doi.org/10.21043/bisnis.v3i2.1494>

Siti, Ai, Ifa Hanifia Senjiat, and Amrullah Hayatudin, 'Tinjauan Fiqh Muamalah Tentang Upah Pemeliharaan Hewan Ternak Pada Akad Ijarah (Praktik Gadub Sapi)', Prosiding Hukum Ekonomi Syariah, $2020<$ https://doi.org/10.29313/syariah.v0i0.19340>

Sri Wahyuni, Nining, 'Analisis Fikih Sistem Pembiayaan Muḍārabah Dalam Praktik Dan Peraturan Perundang-Undangan Perbankan Syari’ah’, FITRAH:Jurnal Kajian Ilmu-Ilmu Keislaman, 2.1 (2016) < https://doi.org/10.24952/fitrah.v2i1.458>

Subaiti, Berkah, Istianah Istianah, and Wage Wage, 'Pandangan Hukum Islam Terhadap Kerja Sama Gaduh Sapi Di Desa Lembupurwo Kecamatan Mirit Kabupaten Kebumen', Jurnal Hukum Ekonomi Syariah, 2.1 (2019) <https://doi.org/10.30595/jhes.v2i1.4474>

Sulaiman Rasjid, Fiqh Islam, (Bandung: Sinar Baru Algensido, 2017

Susi Tri Wahyuni, and Kusni Hidayati, 'Program Pengembangan Kandang Intensif Ternak Sapi Gaduh Di Trenggalek', Ekobis Abdimas: Jurnal Pengabdian Masyarakat, 1.2 (2020) <https://doi.org/10.36456/ekobisabdimas.1.2.3035>

Syarifuddin, Amir, 'Garis-Garis Besar Fiqh', Katalog Perpustakaan Badan PPSDMK Kemenkes RI, 2010 